\title{
Spotted around the web: Antisense therapies, mosaic mutations, researcher productivity
}

\author{
BY JILL ADAMS
}

12 NOVEMBER 2021

WEEK OF NOVEMBER $8^{\text {TH }}$

\section{Research roundup}

- Vocalization patterns at 12 months may predict a future autism diagnosis among infants with an autistic sibling. Child Development

- A brain response to sound called the N1 auditory evoked potential may differ between autistic and non-autistic people. Journal of the American Academy of Audiology

- Viewing autism as a set of deficits - a conventional medicine approach - may constrain broader thinking about neurodiversity in society. Journal of Child Psychology and Psychiatry

- Researchers have treated multiple children with rare genetic diseases using custom antisense oligonucleotides that obscure short, pathogenic stretches of DNA. Science

- Autism and intellectual disability in two siblings likely resulted from SCN2A mutations in a small proportion of their father's sperm, a case study finds. Spectrum wrote about such 'mosaic' mutations in July. Journal of Medical Genetics

- Mice missing the autism-linked gene CNTNAP2 have altered spatial skills, memory processing and neuronal activity in the hippocampus. Cell Reports

\section{Science and society}

- The Autism Science Foundation issued a statement in support of applied behavior analysis. Spectrum has covered the controversial therapy in depth. Autism Science Foundation

- The Canadian-Israeli Azrieli Foundation has made a \$13 million donation to the National Autism Research Center in Beersheba, the largest gift ever to support autism studies in 


\section{Spectrum | Autism Research News}

https://www.spectrumnews.org

Israel. The Times of Israel

- In Canada, the province of British Columbia intends to switch its autism support funding to a hub system that spans a broader set of childhood needs, leaving autism advocates and families uncertain if they'll lose their current services. Global News

- Science historian and writer Brandy Schillace discusses embracing her gender identity and neurodiversity in a personal essay. Scientific American

Know thyself: Painting by essay-writer Brandy Schillace, entitled "Fledging"

Courtesy of Brandy Schillace

- The coronavirus pandemic has impacted the productivity and mental health of researchers, particularly women, people of color and parents of young children. Nature

- A federal effort to oversee autism research and healthcare services in the United States has requested public comment by 30 November for next year's strategic plan. Interagency Autism Coordinating Committee

- Parents of autistic children living in the United Kingdom have reported more difficulty in getting school-based support services than they did four years ago, according to a report by the National Autistic Society. The Guardian

- The U.S. Justice Department has sued Uber for charging extra fees when drivers wait for passengers to arrive, saying it discriminates against people with disabilities. The New York Times 